\title{
MARGINAL EMPLOYMENT SUBSIDIZATION: A NEW CONCEPT AND A REAPPRAISAL
}

\author{
ANDREAS KNABE \\ RONNIE SCHOEB \\ JOACHIM WEIMANN
}

CESIFO WORKING PAPER NO. 1707

CATEGORY 4: LABOUR MARKETS

APRIL 2006

\begin{abstract}
Presented AT CESifo AREA CONFERENCE ON EMPLOYMENT AND
SOCIAL PROTECTION, MAY 2006
\end{abstract}

\footnotetext{
An electronic version of the paper may be downloaded

- from the SSRN website:

www.SSRN.com

- from the RePEc website:

www.RePEc.org

- from the CESifo website:

www.CESifo-group.de
} 


\title{
MARGINAL EMPLOYMENT SUBSIDIZATION: A NEW CONCEPT AND A REAPPRAISAL
}

\begin{abstract}
In this paper, we attempt to renew the interest in marginal employment subsidies. Such subsidies are paid only for a firm's additional employment exceeding some reference level and create larger employment stimuli at lower fiscal costs than general wage subsidies for all workers. If the hiring of a new employee also entails subsidizing an incumbent worker (double marginal subsidization), the replacement of regular paid workers by outsourcing employment to newly established firms - a standard critique of marginal employment subsidies - can be avoided. This additional subsidy reduces the incentive to crowd out regular employment and results in even larger employment effects. Applying the subsidy scheme to the low-skill labor market in Germany, we show that employment can be substantially increased without imposing additional fiscal burden.
\end{abstract}

JEL Code: J38, J68, H25.

Keywords: unemployment, marginal employment subsidies.

\author{
Andreas Knabe \\ Department of Economics and \\ Management \\ Otto-von-Guericke-University \\ P.O. Box 4120 \\ 39016 Magdeburg \\ Germany \\ andreas.knabe@ww.uni-magdeburg.de \\ Ronnie Schoeb \\ Department of Economics and \\ Management \\ Otto-von-Guericke-University \\ P.O. Box 4120 \\ 39016 Magdeburg \\ Germany \\ ronnie.schoeb@ww.uni-magdeburg.de \\ Joachim Weimann \\ Department of Economics and Management \\ Otto-von-Guericke-University \\ P.O. Box 4120 \\ 39016 Magdeburg \\ Germany \\ joachim.weimann@ww.uni-magdeburg.de
}




\section{Introduction}

Unemployment is one of the most pressing economic problems of our times. Large European countries, in particular, suffer from mass unemployment and have not found an appropriate cure yet. Although total unemployment is high, large differences exist between different qualification levels. While unemployment of college graduates is relatively low, the market for low-skilled labor is in a deep crisis. OECD unemployment rates of low-skilled persons are on average more than twice as high as those of high-skilled persons.

On a global level, the literature identifies two reasons for this development. First, skillbiased technological progress raises the complementarity between capital and high-skilled labor and the substitutability between capital and low-skilled labor. Hence, capital accumulation widens the productivity gap between the different qualification levels and worsens the relative position of the low-skilled (Falk and Koebel 2002). Second, economic integration and international trade threaten either the income position or the jobs of the lowskilled in the developed world. ${ }^{1}$ As a consequence, low-skilled individuals have to accept lower wages - which drives them into the "working poor" - or they are forced out of the labor market. The latter happens in countries with generous welfare systems that provide wagereplacement benefits that implicitly result in too high minimum wages: wages firms are willing to pay become too low to induce the low-skilled to work, and wages at which the lowskilled are willing to work are not affordable by firms. This wedge is widened by taxes and social security contributions.

Wage subsidies may be a possible remedy to this problem. If reservation wages exceed the productivity levels of the low-skilled, the government could pay the difference to close the gap and thereby restore the low-wage segment. Kaldor (1936) was the first to propose a general wage subsidy. The main drawback of such a general wage subsidy, however, is its

\footnotetext{
${ }^{1}$ For evidence for the impact of technological progress and international integration on low-skill employment and wages see Acemoglu (2002), Johnson and Stafford (1999), Hijzen et al. (2005), and the references cited therein.
} 
fiscal cost. Wage subsidies have to be paid for all employees, although the labor demand stimulus works only at the margin. This creates large windfall gains for already existing employment. Firms receive the subsidy even if they do not create a single new job.

In principle, wage subsidies can be given to either employers or employees or to both sides. Standard tax incidence analysis shows that in flexible markets it does not matter to which side a subsidy is given. Market forces will always shift the subsidy such that an identical equilibrium outcome is obtained in both cases. ${ }^{2}$ If market forces are impaired, however, for example by minimum wage legislation or a union wage setting, tax incidence becomes different. ${ }^{3}$ In such situations, it depends on whether policy aims at stimulating labor supply or labor demand. When gross wages are rigid, for instance, wage subsidies to employers will promote employment while wage subsidies for employees will only raise the net income of incumbent workers.

An efficient way to reduce the fiscal burden is to restrict the subsidy to additional employment, so that the subsidy is paid only for additional employment compared to some reference level. Such so-called marginal employment subsidies could lower marginal labor costs by a much larger amount than an equal-cost general subsidy and thus create more employment, or, alternatively, create the same marginal stimulus at lower costs.

Even though the fiscal advantage seems obvious, marginal employment subsidies have received rather little attention in the economic literature and do not play a major role in the current policy debate. The main attempt of this paper therefore is to renew the interest in marginal subsidy schemes by discussing a recent proposal for Germany. The so-called Magdeburg Alternative suggests a permanent rebate of the social security contributions of additional employees to their employers. This reduces labor costs at the margin without affecting net wages. The problem with such a scheme is, however, that firms can replace regular paid workers by outsourcing employment to newly established firms. To avoid this effect, the Magdeburg Alternative allows for a double marginal subsidization for incumbent

\footnotetext{
${ }^{2}$ For a simple exposition of this result in the context of employment subsidies, see Borjas (2000, p. 170).

${ }^{3}$ The theory and empirical evidence of the effects of taxes and subsidies under different wage setting regimes are analyzed by Daveri and Tabellini (1999).
} 
firms. If an incumbent firm hires a formerly unemployed worker in excess of its reference employment level, it receives the subsidy not only for the new employee, but also for one incumbent employee. This reduces the incentive to crowd out regular employment and results in even larger employment effects. This can be achieved without imposing additional fiscal burden.

We proceed as follows. In the next section, we present some stylized facts on the extent and causes of low-skill unemployment. In Section 3, we review the existing literature and discuss the requirements for an efficient wage subsidy scheme for the low-skilled in Continental European type of welfare states. Section 4 briefly reviews employee-oriented wage subsidy programs and discusses their limitations in rigid labor markets. Against this background, we then present in Section 5 the Magdeburg Alternative and conduct simulations to estimate its employment and fiscal effects. Section 6 concludes.

\section{The three types of welfare states: Some stylized facts}

If one wants to analyze the causes of unemployment among the low-skilled, it is helpful to revert to the commonly applied distinction between Anglo-Saxon, Continental European, and Scandinavian welfare states. Following Scharpf (2000), Anglo-Saxon welfare states are characterized by systems of limited formal welfare that is sufficient to prevent poverty, but cannot maintain living standards of higher paid workers. They have a political commitment to full employment on a private sector basis, provide little employment protection, and exhibit low levels of active labor market policies. On the other hand, Scandinavian welfare states provide mainly tax-financed, earnings-related benefits, show a high level of active labor market policies, and a large share of public employment. The Continental European welfare states also provide earnings-related benefits which are, however, mainly financed by wagebased contributions. Active labor market policies and public employment are more important than in the Anglo-Saxon countries, but do not reach the levels of the Scandinavian welfare states. In this section, we will examine how the three different types of welfare states cope with low-skilled unemployment. 
Figure 1: Low-skill unemployment in the OECD (2003)

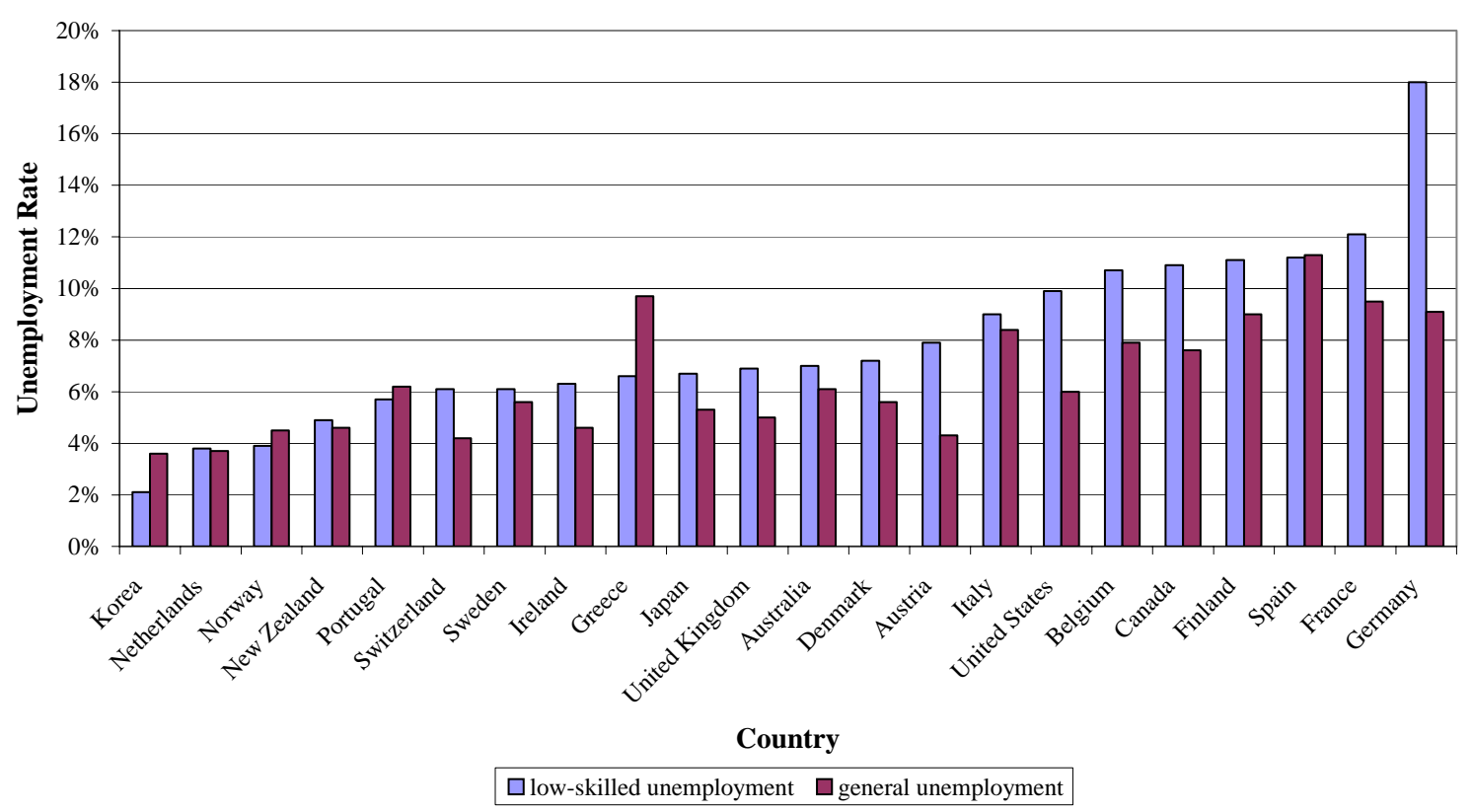

Source: OECD (2005).

Note: The total unemployment rate refers to the standardized unemployment rates. Low-skilled persons are considered to have completed less than an upper secondary education.

Figure 1 compares the unemployment rates of low-skilled persons in 22 OECD-countries with the general unemployment rate. Two observations are noticeable. First, unemployment is generally more prevalent among the low-skilled than among higher qualified groups. In most countries, the unemployment rate of the low-skilled exceeds the general unemployment rate, the exceptions being the Southern European countries Greece, Portugal, and Spain, as well as Norway and Korea. This highlights the fact that the low-skilled form a distinct subgroup of the labor force whose unemployment experience differs from that of the rest of the population and therefore requires special attention.

Second, low-skilled unemployment rates vary much more across countries than general unemployment rates, even though both are positively related. ${ }^{4}$ While general unemployment rates range from 3.6 percent (Korea) to 11.3 percent (Spain), low-skilled unemployment rates

\footnotetext{
${ }^{4}$ The (unweighted) coefficient of variation is 0.35 for the total unemployment rate and 0.44 for the low-skilled unemployment rate. The Spearman rank correlation coefficient is 0.758 .
} 
lie between 2.1 percent in Korea and 18.0 percent in Germany. Among the countries with the highest unemployment rates of low-skilled persons, we find the large Continental European countries France, Spain, Italy, and, with an extraordinarily high rate, Germany. Strikingly, the North Americans also score less well than most other countries in the OECD.

At first sight, it seems impossible to explain the variation in low-skilled unemployment by making the standard distinction between flexible, Anglo-American style labor markets and rigid European labor markets, because both types of economies appear on both ends of the spectrum. To shed some light on the determinants of low-skill unemployment rates, we distinguish three different types of welfare states: the Anglo-Saxon type (e.g. US, UK, Ireland, Australia), the Continental type (e.g. Germany, France, Italy) and the Scandinavian type (e.g. Norway, Sweden, Denmark). Common economic shocks are absorbed differently by each type, which might help to explain some of the variation in unemployment rates.

Employment of low-skilled labor is faced with similar obstacles in all OECD economies. Economic integration and biased technological progress have caused relative demand for lowskilled labor to decline. Since both phenomena mainly affect those sectors that produce internationally tradable goods, the released low-skilled workers could be absorbed by the domestic service sector. Domestic services, however, typically provide low-productivity, lowpaid jobs. When the productivity of these jobs is only slightly above the level of welfare benefits, which define the lowest reservation wage, taxes and social security contributions (SSC) have a destructive effect on low-skilled employment. They destroy many additional job opportunities in the domestic service sector. There is clear empirical evidence in favor of this hypothesis. Figure 2 shows how the employment share in domestic services relates to the tax and SSC wedge of a low-paid worker. ${ }^{5}$ There is a strong negative relation between the two variables $\left(R^{2}=0.49\right)$ : the low-wedge countries have employment shares of between 20 and 25 percent, while the high-wedge countries employ only about 15 percent of their labor force in domestic services.

\footnotetext{
${ }^{5}$ Following Scharpf (2000), we use the employment in ISIC 6 and G/H (wholesale and retail trade, restaurants, and hotels) as a proxy for domestic low-skill service employment. We do not take into account ISIC 9 (community, social, and personal services) because it also includes public sector jobs and jobs with high labor productivities (e.g. in education).
} 
Figure 2: The impact of the tax wedge on employment in domestic services (2002)

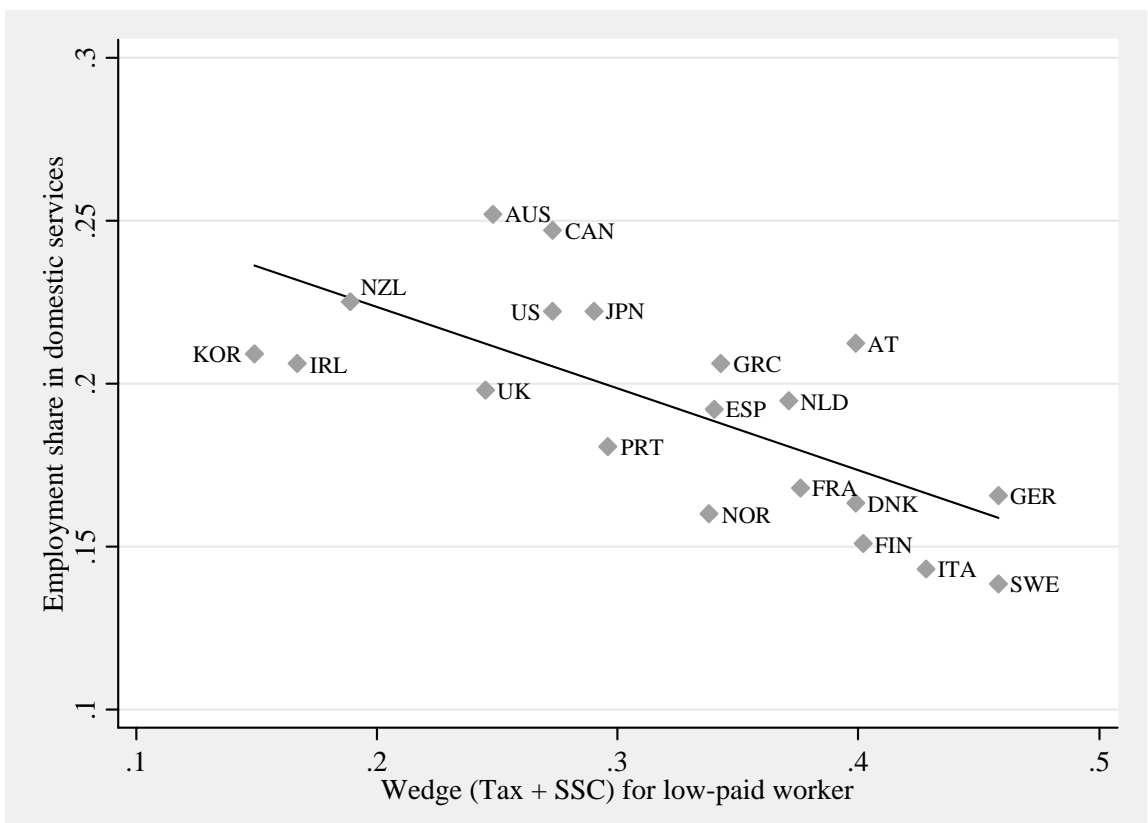

Source: OECD (2004), OECD Labour Market Statistics.

Note: The wedge for a low-paid worker refers to income tax plus employee and employer social security contributions less cash benefits as a percentage of gross earnings for a single person without children at 67 percent of average earnings. The employment share in domestic services is approximated by ISIC 6 or G/H (wholesale and retail trade, hotels and restaurants).

If low-skilled workers are driven out of the sectors exposed to international trade in all countries, but high-tax countries are not capable of creating new employment opportunities in domestic services, one should observe a strong positive relation between the wedge on lowpaid workers and low-skilled unemployment. As Figure 3 shows, there is indeed a positive relation between the two variables, but it is less pronounced $\left(R^{2}=0.25\right)$. While the lowwedge countries consistently show low unemployment rates among the low-skilled, there is a wide dispersion of unemployment rates among the high-wedge countries. For example, Sweden and Germany have about the same wedge (46.1 and 46.6 percent, respectively), but the low-skilled unemployment rate in Sweden is only 6.1 percent, compared to Germany with an appalling 18.0 percent. 
Figure 3: The impact of the tax wedge on low-skill unemployment (2003)

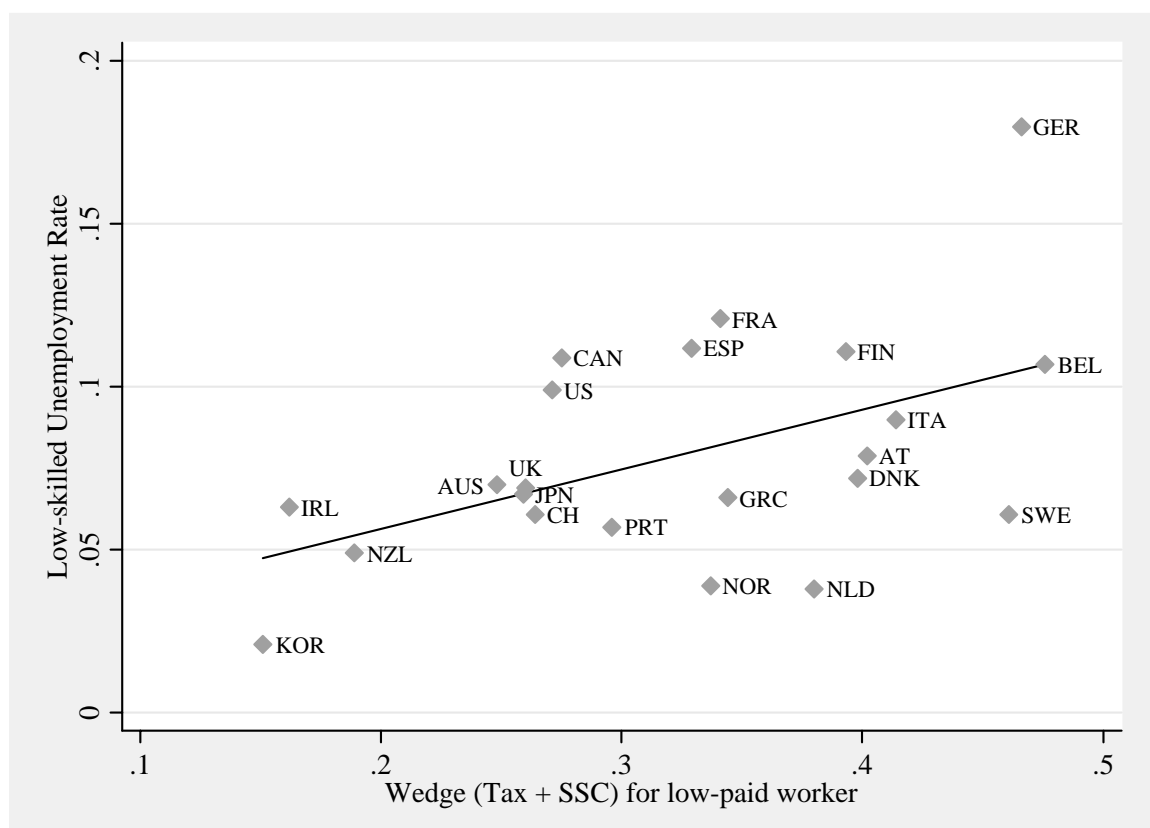

Source: OECD $(2004,2005)$.

Note: The wedge for a low-paid worker refers to income tax plus employee and employer social security contributions less cash benefits as a percentage of gross earnings for a single person without children at 67 percent of average earnings. Low-skilled persons are considered to have completed less than upper secondary education.

The formal wedge thus fails to be a good predictor of low-skilled unemployment among the high-wedge countries. Closer examination of Figure 3 shows that there appears to be a pattern in the unemployment experience of high-wedge countries. If one looks at which countries cluster above and below the regression line, one finds that the Continental European welfare states Germany, France, and Spain lie above the line, while the Scandinavian countries Norway, Sweden, and Denmark are below. The two types of high-wedge welfare states seem to deal with low-skilled (un)employment in quite different ways. One possible explanation is the extent to which the state takes an active role in creating employment opportunities for its unemployed. If the high wedge prohibits low-skilled unemployed from being absorbed by the private service sector, the state could step in. In fact, public sector employment differs immensely between the Continental European and the Scandinavian countries (Figure 4). The Continental European countries employ between 15 and 20 percent of their labor force in the 
public sector, which is the same range as for most low-wedge countries. In contrast, the Scandinavian countries have public sector employment shares between 34 and 38 percent.

Figure 4: The tax wedge and public sector employment (2003)

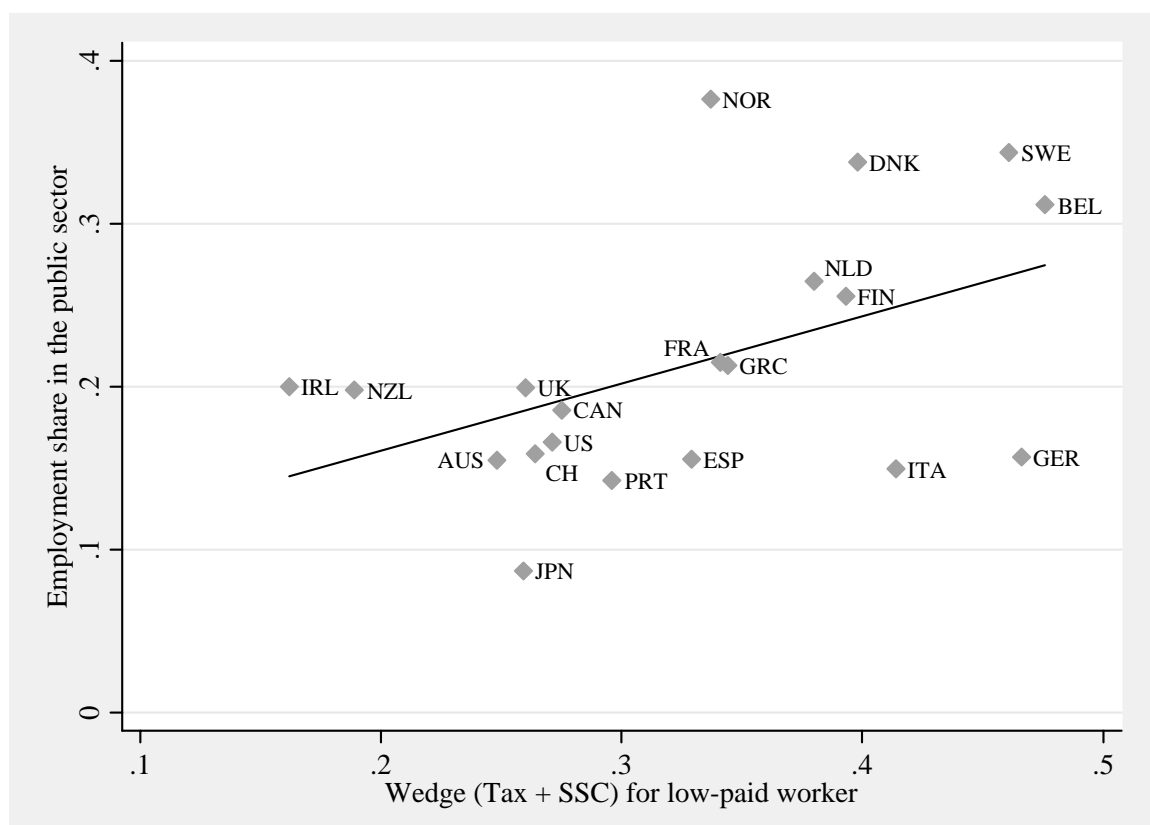

Source: OECD (2004), ILO LABORSTA Database.

Note: The wedge for a low-paid worker refers to income tax plus employee and employer social security contributions less cash benefits as a percentage of gross earnings for a single person without children at 67 percent of average earnings. Public sector employment covers all employment of the general government sector plus employment of publicly owned enterprises and companies.

To test whether public sector employment can explain the wide variation of unemployment rates among the high wedge countries, we conduct a simple regression to illuminate the distinct impact of the wedge and public employment on the low-skilled unemployment rate. We find the following relation:

$$
\text { Unemployment Rate }=\underset{(0.025)}{0.050}+\underset{(0.080)}{0.263 *} \text { Wedge }-\underset{(0.092)}{0.252 *} \text { Public Employment Share } .
$$

Both the wedge and the public employment share have a strong, significant impact on the low-skilled unemployment rate. Including public employment in the regression increases its explanatory power noticeably $\left(R^{2}=0.43\right)$. 
Our quick glance at the data suggests that there are three approaches to dealing with lowskilled unemployment. The Anglo-Saxon countries have relatively low tax and SSC rates on low-pay workers, which enables them to channel their low-skilled workforce into private services. Both the Continental European and the Scandinavian countries have high tax and SSC rates on low-paid workers resulting in a lower share of low-skilled employment in the domestic private service sector. The Scandinavian countries, however, use public sector employment as a substitute and thereby keep low-skill unemployment at low levels. The Continental European countries, by contrast, combine high tax and SSC rates with low public employment, and thus experience high unemployment among their low-skilled labor force.

The data suggest two policy options to fight low-skill unemployment: reducing the wedge and/or increasing public employment. The latter option, however, is not advisable for Continental European countries. First, public budgets are already under considerable strain, so that further public spending programs cannot be implemented. Second, public employment as a labor market instrument is most efficient if it emulates the first-best, private sector employment that would exist in a perfectly functioning labor market. This, however, can best be achieved if the government sets the right incentives to create employment directly in the private sector. Therefore, the best policy advice to give is to fight low-skill unemployment by reducing the burden imposed on low-paid workers through reductions in taxes and, especially, social security contributions without placing additional burden on the public budget.

\section{Marginal employment subsidies}

In this section, we briefly review the existing literature on marginal employment subsidies and discuss the requirements for a successful wage subsidy scheme in Continental European countries.

\subsection{Theory and practical experience}

Wage subsidies in general may be a possible remedy to narrow the wedge described in the last section. Kaldor (1936), who was the first to propose a general wage subsidy, found recent 
support for his proposal. Phelps (1997), for instance, proposes a graduated tax subsidy scheme to firms for every low-wage worker they employ. Snower (1994) and Orszag and Snower (2000, 2003) recommend an “employment voucher”, a temporary employment subsidy for hiring the unemployed. Marginal employment subsidies (MES), however, have received rather little attention in the economic literature. Among the few contributions, the most prominent analysis of MES is presented by Layard and Nickell (1980). They implement a MES in both a Keynesian-type and a monetarist macroeconomic model. In their model, the reduction in marginal production costs mainly benefits the international competitiveness in the export sector, which, through its feedback effects on the domestic economy, increases overall output and employment. They conclude that a MES can generate more jobs than a general subsidy costing the same amount. Since this result holds both in the Keynesian and the monetarist version of their model, their analysis strengthens the confidence in the general advantageousness of MES. Whitley and Wilson (1983) develop a dynamic macrosimulation of the Layard/Nickell-model and calibrate it on the British economy. They also find positive employment effects, even though the advantage of MES over general subsidies is less pronounced than proclaimed by Layard and Nickell (1980).

The macroeconomic desirability of MES is emphasized by Rehn (1982). He proposes MES as a complementary measure to expansionary demand policies to avoid the stagflation trap. Expansionary policies, after a short-run positive effect on output and employment, typically cause prices to rise, which counteracts the expansionary effect. With a MES, the expansion of output and employment could instead be connected with falling prices and could therefore reinforce the positive employment effects.

In a conventional neoclassical macroeconomic model, Chiarella and Steinherr (1982) allow for marginal subsidies that are paid for an unlimited duration. Intertemporally optimizing firms, however, expect the program to be abandoned in the future with some positive probability. Their results show that MES can have a significant effect on employment both in the closed and the open economy, without worsening the government deficit.

Analyses of the microeconomic (firm-level) effects of MES are conducted by Oswald (1984) and Hart (1989). Oswald (1984) points out the formal similarities between an inflation 
tax (a tax on price increases) and a marginal employment subsidy. By making use of a dynamic optimization model of profit maximization, he shows that MES, modeled as a continuous function that subsidizes additional employment and taxes layoffs, increase a firm's profit-maximizing employment level. Hart (1989) models a firm’s simultaneous decision over its number of employees and the hours worked per employee. MES have a positive employment effect because they induce the firm to hire more workers and reduce the hours of work. With general subsidies, the substitution effect is reversed if there are quasi-fixed costs per employee (hiring costs, training, etc.), and the employment effects could be negative.

There are also a few real-life active labor market policies that have featured MES. The first such program was started in Germany in 1932. The government paid a tax rebate for a firm's additional employment, measured by the increase compared to a pre-determined reference date. Until December 1932, 62,500 jobs were subsidized (James 1988, p.186). In the 1970s, MES-programs were implemented in many countries. Examples are the New Jobs Tax Credit in the United States (1977/78), the French Prime d'incitation à la création d'emploi (1975), the Small Firms Employment Subsidy in Great Britain (1977), and the Lohnkostenzuschüsse in Germany (1974/75). Even though some of these programs had positive employment effects, their general impact was rather limited. The main reasons were the limited duration for which subsidies were paid, the small magnitude of the subsidies, little knowledge of employers about the programs, bad timing of the reference date, ${ }^{6}$ and the possibility to circumvent the reference date by outsourcing to newly established firms. ${ }^{7}$

\subsection{Institutions matter!}

Wage subsidies may not necessarily be successful. Any potentially successful employment policy has to be clear about the causes of unemployment and pay strict attention to the

\footnotetext{
${ }^{6}$ For example, the German program set December $10^{\text {th }}$, 1974 , as the reference date to which to compare a firm's net employment increase. Since this date was set in the winter, all seasonal employment (agriculture, construction) had to be subsidized in the spring. Rough estimates show that about 75 percent of the subsidized jobs would have been created without the subsidy as well (Schmidt 1979).

${ }^{7}$ For detailed descriptions of the institutional details and evaluations of the programs, see Perloff and Wachter (1979) and Bishop and Haveman (1979) for the US, Layard (1979) for Great Britain, Kopits (1978) for France, and Schmidt (1979) for Germany.
} 
specific institutional setting in which the policy has to be implemented. In what follows, we will illustrate this for the case of Germany.

The German labor market for low-skilled workers is characterized by a two-sided problem. The high level of taxes and social security contributions in combination with implicit minimum wages and unionized wage negotiations have led to too high wages at the bottom end of the wage scale and reduced labor demand substantially. At the same time, the welfare state has cushioned the low-skilled unemployed with benefit payments that are conditioned on not being in employment and discouraged them from searching for employment with transfer reduction rates of up to 100 percent and beyond. A successful employment policy measure thus has to tackle both sides simultaneously to solve the unemployment problem. Lowering gross wages without creating incentives for the unemployed to accept job offers will fail as will improved incentives to accept jobs when gross wages remain high.

According to the existing law in Germany, long-term unemployed low-skilled workers receive welfare benefits according to some defined socio-cultural minimum level of existence. In general, this minimum existence level is not far below the net wage achievable from lowpaid work (cf. Boss and Elender 2005). If workers decided to accept a low-wage job, the high German benefit reduction rates mean that the net gain of a full-time job is typically too small to be attractive. If at all, the German system favors part-time work.

This poverty trap in the German system welfare system is illustrated in Figure 5. A single welfare recipient without children receives a monthly benefit of about 675 Euro (including a housing allowance). Since October 2005, he can keep the first additional 100 Euro without deductions when he accepts a job offer. If he earns more than that, 80 percent (of gross income between 100 and 800 Euro) or 90 percent (of gross income between 800 and 1200 Euro) per additional Euro are deducted from benefits. This increases the incentive to accept part-time jobs while the incentive to search for a full-time job instead is almost eliminated in the current system. Income above 1200 Euro per month is completely deducted from welfare benefits. As the graph illustrates, the lowest wage brackets promise net incomes that barely create sufficient incentives to accept full-time jobs. The poverty trap constitutes the first 
welfare dilemma for the German labor market, because the way the welfare system is constructed creates the cases it is supposed to help.

Figure 5: The poverty trap

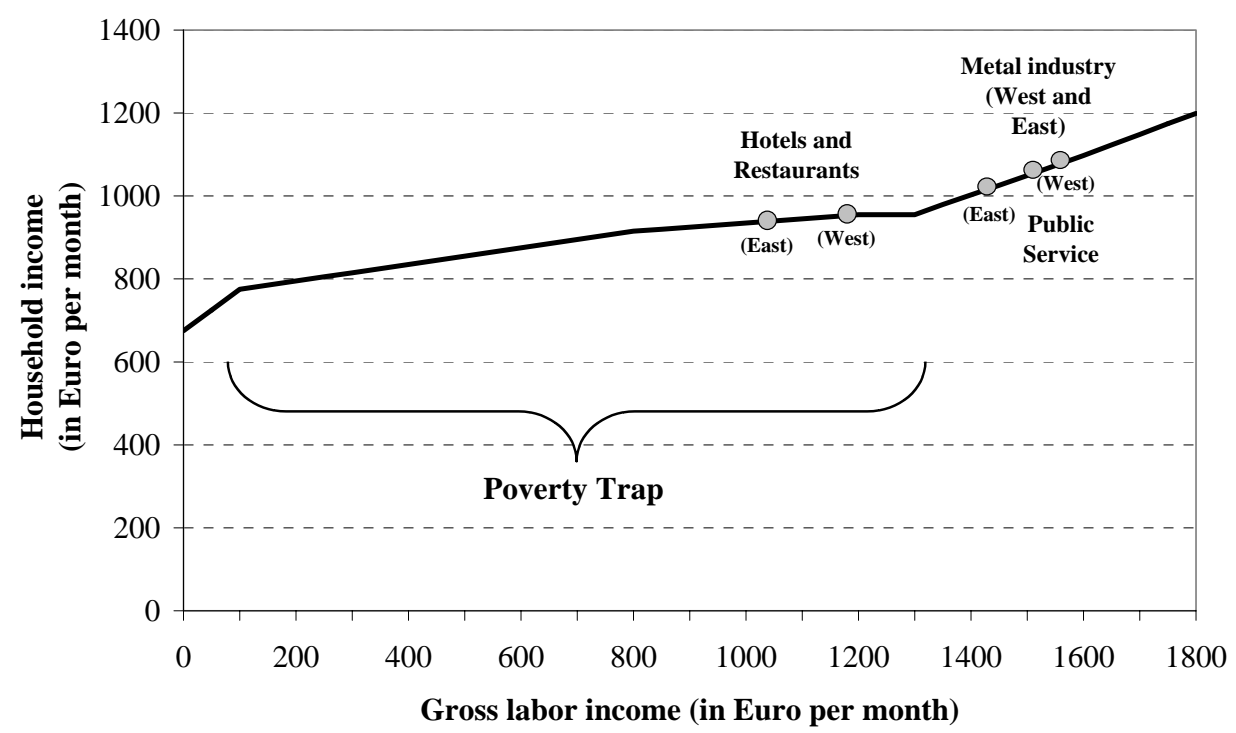

Source: WSI (2004) and own calculations.

Legend: The solid line depicts the net household income of a single welfare recipient, depending on his gross labor income. The dots show the lowest union wage groups in selected sectors.

The demand side of the labor market is impaired with a second welfare dilemma. The welfare system is basically a redistributive means to which one should contribute according to one's ability-to-pay. Unlike the tax system, which exempts income below the minimum existence level from taxation, the social security system considers all persons as able-to-pay when they are employed. All workers have to contribute from the very first Euro onwards to the social security system. This way of identifying ability-to-pay implicitly assumes that every worker is productive enough to both contribute to the welfare system and still have a net income above the minimum level of existence. This is no longer true for an increasing number of low-skilled workers. Their gross reservation wage lies above their value-added, and thus their labor is not demanded by firms anymore. Since the unemployed are already covered by the social security system, the social security contributions they pay when taking up a new job do not create any new entitlements from the social insurance system. Health insurance coverage remains the 
same and additional entitlements on the pension and unemployment insurances are too small to lift individuals above the minimum existence level in case of need. From an economic point of view, social security contributions on low-paid income are thus equivalent to a labor tax. Since this tax raises gross wages above the productivity level of the low-skilled, it actually works like a prohibitive tax on labor. Wage subsidies can be interpreted as an instrument to eliminate the distortions the government has introduced in the first place.

\subsection{Optimal policy design}

The question arises how to design wage subsidies. The way in which wage subsidies work will differ fundamentally between economies with flexible labor markets, in which wages are determined by the law of supply and demand, and highly regulated labor markets, where wages are bargained over between large interest groups. In Germany, collective bargaining is the main institution where rent-sharing rules are set and distributional conflicts between labor and capital are settled. The so-called 'Tarifautonomie' is a constitutional right of employer and employee organizations to negotiate labor contracts without undue governmental interference. This constitutional status leads to the labor organizations using the wage as the main distribution key for the domestic product between labor and capital. Restricting or eliminating this institution will not be possible without risking social unrest and increasing conflicts between workers and employers (cf. Schöb 2002).

If wages are fixed by collective agreements or by explicit or implicit minimum wages, gross wages cannot be altered by a wage subsidy given to workers - at least in the short and medium run. And even in the long run, insiders may be able to defend their position (see Lindbeck and Snower, 1988 and 2001). Net wages, by contrast, cannot be altered by a wage subsidy given to employers. In such an institutional setting, a wage subsidy cannot be shifted easily on either market side, so it does matter whether the subsidy is given to employees or employers. As a consequence, policymakers need to know whether they have to stimulate labor supply or labor demand. If gross wages are too high - for the reasons discussed earlier labor demand should be stimulated by directly subsidizing employers. If, in addition, 
incentives to accept new jobs are lacking, complementary policy measures such as an additional wage subsidy to employees are required.

From a fiscal point of view, any general subsidy - independent of whether it is given to employers or employees - will cause a fiscal deficit at the beginning as it subsidizes existing jobs right from the implementation while it takes some time before a significant number of new jobs lead to a reduction of welfare benefit payments. Public acceptability, however, requires that new labor market reforms do not impose an additional fiscal burden. This constraint not only applies in the long run but must be fulfilled even in the short run. Thus, employment policies must be strictly targeted to actions that directly reduce public expenditures. In other words, an individual job match between an employer and an employee can only enjoy a reduction in taxes and social security contributions if the creation of this match directly reduces unemployment and lowers public welfare expenditures. This rules out across-the-board tax reductions for low-skilled workers, as they are sometimes advocated (cf. German Trade Union Federation 2003).

\section{The American EITC and its European offsprings}

One way to reconcile social policy that aims at providing a minimum income with the economic fact that in many cases low-skilled productivity may not be sufficiently high to pay for it is to "make work pay." Instead of paying wage-replacing benefits that are decreased if a person starts working, the state could pay wage-supplementing benefits that increase a person's income if he decides to leave welfare and accepts a low-paid job. Such employmentconditional benefits serve two purposes: they lower the wedge on low wages, thereby stimulating employment, and at the same time serve as a redistributive measure that raises low wages to socially acceptable levels.

The "prototype" of such employee-oriented subsidies is the Earned Income Tax Credit (EITC) in the United States, which was introduced in 1975 as a modest program to offset social security payroll taxes for low income families with children. Subsequent reforms (major expansions in 1986, 1990, and 1993) made it one of the largest welfare programs in 
the US. The EITC grants a tax credit to low-income earners that functions like an employeeoriented wage subsidy. For low family income, each additional dollar earned is rewarded by a 40 cent tax credit (phase-in). Thus, a family can receive a maximum of US\$ 4,008 in addition to a market income of US\$ 10,020 . If family income exceeds US\$ 13,090 , the EITC is gradually reduced (phase-out). In this income range, the benefit reduction puts a burden of 21 cent on each additional dollar earned by the family.

Similar programs have been introduced in European countries as well, even though on a much smaller scale than in the United States. While the maximum amount of the EITC corresponds to 13.4 percent of the full-time median wage in the US, Britain pays a maximum of 10.3 percent, the Netherlands 3.4 percent, France 3.3 percent, and Belgium 1.3 percent (cf. OECD 2003, p. 159). In Germany, the switch from wage-replacing benefits to wagesupplements is also being discussed. The most prominent proposal is called Activating Social Welfare (Sinn et al. 2002, 2006) developed by the Munich-based Ifo institute. The European Economic Advisory Group at CESifo is propagating the same idea as a "Proposal for Europe" (Corsetti et al. 2002, Ch. 6). Activating Social Welfare comprises three steps necessary for a successful reform. First, welfare benefits for recipients who are able to work have to be reduced significantly (up to 53 percent) so that staying on welfare without working can only be affordable for persons who have other sources of income (e.g. from moonlighting). Second, a tax credit subsidizes low incomes such that even for low-wage work net incomes are higher than current welfare benefits. Third, for those on welfare who cannot find a job on the labor market even though they are willing to work, the state has to step in and provide public employment opportunities.

The first two steps are the typical ingredients of the "making-work-pay” recipe. While the introduction of wage-supplementing elements is rather uncontroversial, the substantial reduction of basic welfare levels would be in harsh conflict with the legal minimum income definitions in most European countries. Welfare recipients who are willing to work but cannot find a job have the right to their socio-cultural minimum of existence. Step three of Activating Social Welfare is meant to circumvent this problem. If a person is not able to find a job in the labor market, the state will provide jobs in public employment companies. These jobs will pay 
a wage equal to the current level of welfare benefits, so that nobody willing to work will have to live below the minimum of existence. If a welfare recipient refuses to take a job in a public employment company, he can be expected to have better sources of income and can live with reduced benefits. ${ }^{8}$ The establishment of public employment thus functions as a self-selection device: currently, the alternatives of the welfare system are either working for low wages or staying at home with slightly less benefits. With public employment programs, the options become either working for low wages or working for welfare benefits. Faced with these alternatives, only the truly needy will accept the public "workfare" jobs, others will refuse to work (legally) and have to accept drastically reduced benefits. ${ }^{9}$

To avoid "revolving-door" effects, i.e. that firms simply replace already employed workers with subsidy-recipients, all workers, no matter whether previously employed or not, have to receive the tax credit. Of course, this will increase the fiscal burden of the reform proposal, but corresponds to the more general goal of creating a low-wage sector without creating "working poor." For Sinn et. al. (2002, 2006), these windfall gains are not undesirable side effects, but a necessary component of a successful reform package.

In an economy with downward rigid wages above market-clearing levels, however, Activating Social Welfare will not create a single new job since it does not lead to a fall in labor costs. What may have been a success story in the United States might become a failure in Continental European countries without complementary policy measures. Deregulation that moves the labor market towards a more flexible structure is one option which trade unions in Germany strongly oppose. If, due to complementary policies, gross wages fall, their members would be the losers of the reform. Only the non-represented outsiders would benefit. But even in a more flexible labor market success may be doubtful. Sufficient wage pressure from outsiders requires that public employment must be provided for all unemployed workers from the very first day Activating Social Welfare is introduced. Otherwise, the labor supply effect

\footnotetext{
${ }^{8}$ This procedure is compatible with most currently existing laws. For example, the German social code states that the state should create public jobs for those welfare recipients who do not find a job and pay them only a small allowance in addition to their benefits (\$16(3) SGB II).

${ }^{9}$ A more formal, albeit very illustrative, analysis of the effects of work-requirements can be found in Besley and Coate (1992).
} 
would be diluted since everyone has a constitutional right to receive the legal minimum income. Pure employee-oriented subsidies need market forces to shift the subsidies to the market side where they are needed. Thus, such a subsidy scheme must be embedded in a fullscale de-unionization of the labor market. If the reformers miss this ambitious goal because of the resistance of unions and incumbent employees, they will fail to create new jobs and leave behind huge fiscal deficits.

\section{Employer-oriented subsidies: The Magdeburg Alternative}

Since the transmission mechanism of employee-oriented subsidies to lower wages is impeded by strong labor unions and other rigidities, the alternative is to grant subsidies to the employer. This is the key element of a proposal that two of the authors have launched in the German political discussion under the name Magdeburg Alternative (Schöb and Weimann 2003, 2005). As pointed out above, a wage subsidy alone may not be sufficient to create jobs. The Magdeburg Alternative therefore comprises four elements that take account of the twosided labor market problem, eliminate potential displacement effects, and allow for a permanent change from welfare to workfare in a way that does not require further fundamental reforms.

\subsection{The four elements of the Magdeburg Alternative}

\section{Reimbursing social security contributions for the lowest wage group}

The Magdeburg Alternative reimburses the employers the total amount of social security contributions, i.e. employees' and employers' contributions, if they hire a long-term unemployed welfare recipient. Reimbursement requires that the wage for the new job does not exceed the wage in the current lowest union wage bracket for the particular sector. In Germany, this would reduce labor costs by $35 \%$ in the low-skilled labor market segment. ${ }^{10}$

\footnotetext{
${ }^{10}$ German social security contributions amount to a total of 42.4 percent, which is split between employees (21.65 percent) and employers (20.75 percent). The employer's part is added onto official gross wages. The effective reduction of labor costs is thus $1-(1-0.2165) /(1+0.2075)=0.351$.
} 
Since labor costs are reduced immediately, firms benefit as of the first day of the reform, which is different to employee-oriented subsidies, these having to rely on a functioning transmission mechanism translating higher net wages into lower labor costs. The net wage of newly hired workers is exactly the same as that of incumbent workers.

\section{Double marginal subsidization: additional reimbursement for existing jobs}

Employer-oriented wage subsidies can be implemented in two ways. They are general when they are granted for both incumbent and new workers. This makes them very expensive - in the introductory phase in particular since firms receive subsidies for incumbent workers even before they start hiring additional workers. Alternatively, one can target the subsidy. In this case, the displacement of incumbent workers by subsidized workers and outsourcing endanger the success of such a scheme and raise the fiscal burden too. Our proposal provides two mechanisms to prevent these undesirable side effects.

To avoid displacement of the incumbent workers within the firm, the subsidy is paid only if low-skilled employment in the firm increases compared to the employment level at a certain reference date: only the number of workers exceeding this level will be subsidized. The reference date has to be in the past so that firms cannot adjust the number of workers immediately before it. ${ }^{11}$

Even if displacement in the same firm can be prevented by subsidizing new employees only, a firm could still outsource its low-skilled employees. In a new firm, all low-skilled workers would be subsidized. Outsourcing would yield the same effects as displacement within the same firm. But outsourcing is not costless. A new firm has to be established, administrative costs increase, production plans have to be reorganized, new employees (former welfare recipients) need to receive some training, etc. Although these costs have to be compared with the savings of outsourcing, a saving of 35 percent of the labor costs will still

\footnotetext{
${ }^{11}$ Real-life marginal employment subsidy programs frequently feature a reference date. For example, the first such program, the German Steuergutscheine für Mehrbeschäftigung (tax rebate for additional employment), set the employment on August 15th, 1932, or the average employment between June and August 1932, whichever was higher, as the reference employment level (Marcon 1974, p. 192).
} 
probably be high enough to encourage large-scale outsourcing. This would render the reference date solution ineffective - at additional cost.

To make outsourcing unattractive, the Magdeburg Alternative subsidizes not only new employees but also incumbent employees: for each newly hired low-skilled worker one incumbent worker also becomes eligible for the subsidy. This double marginal subsidization constitutes an incentive to keep old employees in the firm since it changes the marginal calculus of the firm. Obviously, if the hiring of one new employee also reduces labor costs for an old employee, the marginal costs of labor are even lower than with the single marginal subsidy. Hiring a new employee pays twice the subsidy, such that marginal labor costs are reduced by nearly 70 percent.

Figure 6: Double marginal subsidization

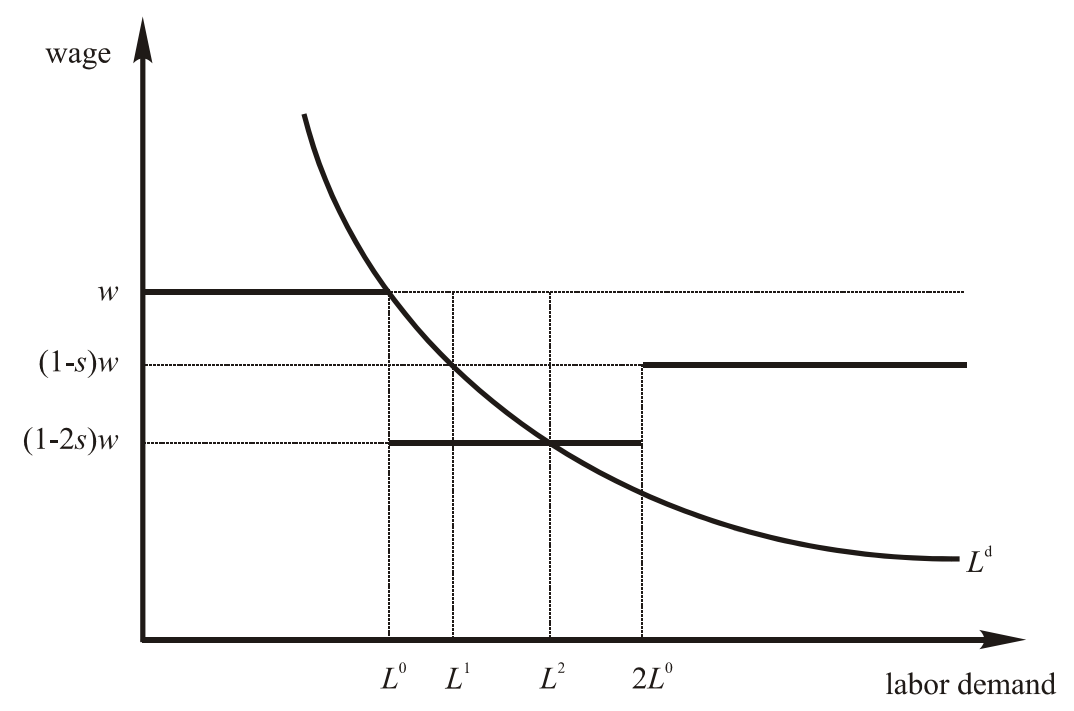

Figure 6 demonstrates the functioning of double marginal subsidization for a single competitive firm. The firm's labor demand curve is given by $L^{d}$, the status quo labor cost is denoted by $w$. The profit-maximizing labor demand is at $L^{0}$. If the subsidy is restricted to the social security contributions of new employees, the marginal wage rate would drop to $(1-s) w$, where $s$ is the single subsidy rate. The profit-maximizing level of employment would be at $L^{1}$. Double marginal subsidization reduces the marginal wage rate even further to $(1-2 s) w$. Of course, this further reduction increases labor demand even more to $L^{2}$. Hence, 
the subsidization of the old workforce being conditional on the creation of new jobs leads to even stronger employment gains.

The incumbent firms thus face lower marginal labor costs, since a new firm receives only the single marginal subsidy for all its employees. The subsidy, however, always reduces a new firm's average labor costs by $s$ percent while the average labor costs of the incumbent firm only falls as the firm increases employment. Its reduction in average labor costs is only $2 s\left(L-L^{0}\right)$, which is smaller than $s L$ as long as $L<2 L^{0}$. This disadvantage, however, is desired: an established firm can only compensate its cost disadvantage compared to new firms by expanding its employment. Only if the established firm doubles its employment does it obtain the same reduction in average labor costs as a new firm.

\section{Improving labor supply incentives}

Germany has a two-sided labor market problem. An employer wage subsidy will only cure labor demand but will fail to promote labor supply of those on welfare. Complementary measures are necessary. Instead of providing costly subsidies to employees, the Magdeburg Alternative proposes to tighten eligibility rules: if someone refuses to work, he will lose his welfare benefit payments. In Germany, the existing social code (§31 SGB II) allows the employment agency to reduce the welfare benefits by 30 percent if a recipient refuses to work. Repeated refusals can even lead to full cancellation of benefits: if someone is given the opportunity to provide for himself and repeatedly refuses to do so, he cannot rely on society's support. These rules are only applied to those able, but not willing, to work. People in need, whether they are unable to work or cannot find a job, will receive their socio-cultural minimum income as before. Social security’s important role as the "lowest safety net" stays untouched - only the often-cited "hammock" is torn down. Rather than increasing the remuneration for work, the incentives to work are raised by lowering the reservation wage via a "tax on voluntary idleness". 


\section{Unlimited duration}

The fundamental problem of the market for low-skilled labor is that the productivity of an increasing fraction of the workforce falls below the implicit minimum wage defined by the minimum existence level. This level is defined in relative terms, i.e. it relates to average incomes. Since the productivity of the low-skilled does not grow as fast as average productivity, more and more low-skilled workers will not be able to earn enough to cover their minimum level of existence by their own means. Welfare systems with traditional wagereplacement benefits will consequently exclude a growing fraction of the labor force from the labor market.

Wage subsidy schemes - including the Magdeburg Alternative - can move the state towards a workfare system where the government only pays the gap between low-paid wage income and the socially accepted minimum existence level. Such a regime shift, obviously, must be of permanent duration.

Temporary subsidy schemes have another weakness. When the subsidy is of limited duration, a firm will only hire a subsidized person if the worker's productivity is only temporarily below its labor costs, and can be increased by (on-the-job) training, etc. As soon as the subsidy runs out, the worker has to be able to produce a value-added that at least covers his costs or he will be replaced with the next subsidized worker. The resulting "revolvingdoor” effect is typical for limited-duration wage subsidies - it does not increase total employment but creates additional cost due to excessive training. Firms will only expand their demand for low-skilled employment if they can expect long-term benefits from it, which will only happen if firms can rely on permanent labor cost reductions.

As mentioned before, the ceiling below which wages are subsidized is related to existing negotiated wages in the lowest wage bracket. This ensures that incumbent low-skilled workers will not lose and this could thus increase political acceptance. The ceiling must not, however, be conditioned on negotiated wages in the future. Chances would be high that the subsidy then becomes part of the bargaining mass and is redistributed between workers and firms. This would raise wages in the lowest wage bracket and reduce the employment effects. The ceiling must therefore be determined independently of future wage negotiation outcomes. 
For instance, this could be achieved by raising the ceiling according to average productivity. In this case, the ceiling rises proportionately with the socio-cultural existence minimum level, which is also linked to average productivity.

\subsection{Employment and fiscal effects}

The Magdeburg Alternative replaces an existing subsidy for non-employment with one that subsidizes employment instead. It is thus understood as a workfare scheme that allows the state to pay only what the individual cannot provide for himself. To show that this can reduce the state's fiscal burden substantially, we proceed in two steps. We first calculate the fiscal savings of getting a welfare recipient back to work. Then we estimate how many new jobs will be created and present an aggregate cost-benefit analysis that takes account of the additional cost due to double subsidization. These calculations are presented for the specific institutional details of the German welfare and tax systems. Nevertheless, the analysis is sufficiently general to allow its extension to other institutional settings.

\section{Costs and benefits of getting one welfare recipient back to work}

The Magdeburg Alternative subsidizes new jobs up to a ceiling that correspond to the status quo lowest union wage brackets. For our calculation, we assume a ceiling equal to a monthly gross wage of 1,200 Euro. ${ }^{12}$ Since social security contributions amount to 42.4 percent of gross income (health insurance contributions: 14.7 percent; care insurance: 1.7 percent; pension insurance: 19.5 percent; and unemployment insurance: 6.5 percent), the monthly reimbursement is 508.80 Euro. $^{13}$

If a welfare recipient takes up a job, the government saves on his welfare benefits. For a single person without children, the monthly welfare payment is 345 Euro, plus an average housing allowance of 330 Euro. In addition, the government pays the social insurance contributions for unemployed, i.e. it contributes 140 Euro per month to a recipient's health

\footnotetext{
12 The level of gross wages in the lowest wage group in the different sectors ranges from about 1,000 Euro to 1,800 Euro (WSI 2004).

${ }^{13}$ Employees without children pay an additional surcharge of 0.25 percent on their care insurance premium. Since this surcharge discriminates between different types of employees, we will not include it in the reimbursement of SSC to employers.
} 
and care insurances and 78 Euro to his pension insurance. All transfers are paid by the federal government except 29 percent of the housing allowance, which is covered by the municipality.

Previous German workfare experiments have shown that some welfare recipients prefer to decline a job offer, even if that means forfeiting future benefits, e.g. because they work in the shadow economy or can rely on family support. In the German city of Leipzig, a field experiment where all welfare recipients were called on to work full-time in a municipal public works company resulted in refusal rates of one-third (Feist and Schöb, 1998). Other cities report drop-out rates between 24 and 29 percent (German Bundestag, 1998). To present a more cautionary estimate, we assume that only every sixth recipient drops out of welfare instead of taking the job. Fiscal savings will be correspondingly lower.

To a minor extent newly employed workers also pay income taxes, which further reduces the fiscal burden. Income tax revenues are split between the jurisdictions. The federal level and the states receive 42.5 percent each of income tax revenues while the municipalities receive 15 percent. The so-called Solidaritätszuschlag, a tax surcharge levied on individual income tax liabilities, accrues solely to the federal government.

The reimbursement of social security contributions imposes no net burden on the public budget since the fact that an unemployed welfare recipient takes up a job does not affect his claims against the social insurance system. Welfare recipients are fully insured by the health and care insurances and remain so when they take up a new job. Only in case of the pension and unemployment insurances can former welfare recipients claim larger pay-outs. The public pensions of low-wage workers, however, will generally be too small to cover the minimum existence level, so that, again, the residual has to be covered by the welfare system. ${ }^{14}$ Any payment contributed to the pension insurance by a low-wage worker only reduces the future liabilities of the welfare system one to one and is thus revenue-neutral. The same logic applies to the unemployment insurance. All contributions of a low-wage worker reduce the future liabilities of the welfare system in the case of future unemployment. Hence, the subsidy paid

\footnotetext{
${ }^{14}$ In Germany, persons aged 65+ are covered by the Grundsicherung im Alter (basic old-age security), which provides a basic pension at the same level as welfare benefits.
} 
to a newly employed former welfare recipient is completely revenue-neutral. The expenditures of the federal government are equal to the additional income of the public social insurance system.

Table 1: Costs and benefits if a single welfare recipient is placed in a new job

\begin{tabular}{l|cccccc|c}
\hline \hline $\begin{array}{l}\text { Savings (+)/ } \\
\text { Costs (-) }\end{array}$ & $\begin{array}{c}\text { Federal } \\
\text { Level }\end{array}$ & States & $\begin{array}{c}\text { Health } \\
\text { Insurance }\end{array}$ & $\begin{array}{c}\text { Pension } \\
\text { Insurance }\end{array}$ & $\begin{array}{c}\text { Unem- } \\
\text { ployment } \\
\text { Insurance }\end{array}$ & $\begin{array}{c}\text { Munici- } \\
\text { palities }\end{array}$ & Total \\
\hline \hline Health Ins. Contributions & -56.80 & --- & +56.80 & --- & --- & --- & 0.00 \\
Pension Ins. Contributions & -156.00 & --- & --- & +156.00 & --- & --- & 0.00 \\
Basic Old-Age Security & +156.00 & --- & --- & -156.00 & --- & --- & 0.00 \\
Unempl. Ins. Contribution & -78.00 & --- & --- & --- & +78.00 & --- & 0.00 \\
Grant to Unempl. Ins. & +78.00 & --- & --- & --- & -78.00 & --- & 0.00 \\
Income Tax & +20.86 & +20.86 & --- & --- & --- & +7.36 & +49.08 \\
Welfare Benefits & +441.03 & --- & --- & --- & -- & +167.09 & +608.12 \\
Drop-Outs & +88.21 & --- & --- & --- & -- & +46.79 & +135.00 \\
\hline \hline Monthly savings & +493.30 & +20.86 & +56.80 & 0.00 & 0.00 & +221.24 & +792.20 \\
Annual savings & $+5,919.60$ & +250.32 & +681.60 & 0.00 & 0.00 & $+2,654.88$ & $+9,506.40$ \\
\hline \hline
\end{tabular}

Source: Own calculations

Table 1 shows the payment flows if a single welfare recipient is placed in a job with a monthly gross wage of 1,200 Euro. As we have explained above, the reimbursement of social security contributions flows from the federal level to the social insurances and thus nets out in the aggregate. Moreover, additional claims to pension and unemployment insurances directly reduce future welfare liabilities of the federal government. Only the health insurance is a net beneficiary; it enjoys higher contributions without having to provide more services.

While the reimbursement does not constitute a net drain to the public budget, the associated savings are substantial. The largest item is previously paid welfare benefits, which save 675 Euro per new job, split into 441 Euro for the federal level and 167 Euro for the municipalities. ${ }^{15}$ Additional savings of 135 Euro result from drop-outs. Together with

\footnotetext{
${ }^{15}$ With a gross wage of 1,200 Euro, even a single welfare recipient is incapable of leaving welfare completely. Hence, additional welfare benefits of 67 Euro are paid to top up his net wage. This explains why only 608 Euro of 675 Euro welfare benefits are saved.
} 
additional monthly tax revenues of 49.08 Euro, total savings amount to 792.20 Euro per month or 9,506.40 Euro per year.

Similar calculations for different household types (married couples, families with children etc.) show that the savings of bringing one person into work are generally of the same magnitude. The average savings per new job, weighted by the relative frequency of different household types, is 9,261.54 Euro per year. Larger households receive higher benefits, so that bringing them back to work reduces the public welfare load more than for a single recipient without children. At the same time, other tax revenues are smaller and savings from drop-outs are lower because welfare can be reduced only for the person who declines to work.

\section{Aggregate costs and benefits}

Aggregate costs and benefits depend on how many new jobs will be created and how high the additional costs that arise are because the double marginal subsidy and possible displacement effects make it necessary to subsidize already existing jobs. We estimate that about 2.1 million full-time jobs currently exist in the German low-wage sector. ${ }^{16}$ The current number of long-term unemployed welfare recipients is 2.8 million.

As a cautionary guess, we will assume a constant wage elasticity of labor demand of 0.5. Additionally, we will examine an optimistic and a pessimistic scenario with labor demand elasticities of 0.7 and 0.3 , respectively. ${ }^{17}$ Table 2 presents the employment and fiscal effects in all three scenarios. The double marginal subsidy reduces marginal labor costs by 70 percent.

\footnotetext{
${ }^{16}$ To calculate this number, we applied the share of employees in the lowest qualification group, as obtained from the German wage statistic (Hake and Kaukewitsch 2001), to the current number of total employment, and converted part-time jobs into full-time equivalents. The lowest qualification group comprises all jobs that, in case of blue-collar workers, require less than three months experience or that, for white-collar workers, do not require formal vocational training.

${ }^{17}$ This is in line with the empirical literature on the wage elasticity of labor demand. In his survey, Hamermesh (1993) concludes that the most probable interval for the constant-output elasticity is between 0.15 and 0.75 . The unconditional elasticity, which takes output effects into account, lies on average at around unity (Cahuc and Zylberberg 2004, 211). For low-skilled workers, recent studies with German data show that their conditional elasticity is 0.5 in the manufacturing sector and 2.1 in the service sector (Addison et al. 2005).
} 


\begin{tabular}{|c|c|c|c|c|c|c|c|c|c|}
\hline & \multicolumn{9}{|c|}{ Wage elasticity of labor demand } \\
\hline & \multicolumn{3}{|c|}{0.3} & \multicolumn{3}{|c|}{0.5} & \multicolumn{3}{|c|}{0.7} \\
\hline & \multicolumn{3}{|c|}{$\begin{array}{l}\text { Add. displacement } \\
\text { (in percent) }\end{array}$} & \multicolumn{3}{|c|}{$\begin{array}{l}\text { Add. displacement } \\
\quad \text { (in percent) }\end{array}$} & \multicolumn{3}{|c|}{$\begin{array}{l}\text { Add. displacement } \\
\quad \text { (in percent) }\end{array}$} \\
\hline & 0 & 50 & 100 & 0 & 50 & 100 & 0 & 50 & 100 \\
\hline Employment gain (in ‘000s) & 902 & 902 & 902 & 1,714 & 1,714 & 1,714 & 2,058 & 2,058 & 2,058 \\
\hline $\begin{array}{l}\text { Fiscal savings from hiring former } \\
\text { welfare recipients (in mill. } € \text { p.a.) }\end{array}$ & 8,356 & 8,356 & 8,356 & 15,874 & 15,874 & 15,874 & 19,063 & 19,063 & 19,063 \\
\hline Costs of stock subsidy (in mill. $€$ p.a.) & 5,392 & 5,392 & 5,392 & 10,243 & 10,243 & 10,243 & 12,301 & 12,301 & 12,301 \\
\hline Additional displacement (in ‘000s) & 0 & 578 & 1,156 & 0 & 172 & 344 & 0 & 0 & 0 \\
\hline Costs of displacement (in mill. $€$ p.a.) & 0 & 3,454 & 6,909 & 0 & 1,029 & 2,058 & 0 & 0 & 0 \\
\hline Fiscal effect p.a. (in mill. Euro) & 2,964 & -490 & $-3,945$ & 5,631 & 4,603 & 3,574 & 6,763 & 6,763 & 6,763 \\
\hline Fiscal effect per new job (in Euro) & 3,286 & -543 & $-4,372$ & 3,286 & 2,685 & 2,085 & 3,286 & 3,286 & 3,286 \\
\hline
\end{tabular}

Source: own calculations.

In the pessimistic scenario (constant elasticity of 0.3 ), this fall in labor costs leads to a 43.8 percent increase in labor demand. With current employment at 2.1 million persons, this corresponds to 902,216 new jobs. Since each new job saves the public budget 9,261.54 Euro, direct savings are equal to 8.4 billion Euro. From this, one has to subtract the expenditures for the double subsidization. If all new jobs are subject to double subsidization, the additional reimbursement is 508.80 Euro per month and job. The annual costs are thus equal to 5.4 billion Euro. We also assume that remaining regular jobs are partly replaced by subsidized jobs, which in addition raises costs. We present the costs if no, half, or all unsubsidized workers are in some way displaced and have to be subsidized, too. If half or all of these employees have to be subsidized, the additional costs are 3.5 billion or 6.9 billion Euro, respectively. Summing up, the pessimistic scenario results in 902,216 new jobs, but might lead to net fiscal costs depending on the magnitude of displacement. In the most pessimistic case, the annual fiscal costs per new job are 4,372 Euro.

In the medium scenario (elasticity of 0.5), employment increases by 83.3 percent, which would create 1.7 million new jobs. Direct savings are 15.9 billion Euro, 10.2 billion are spent on the stock subsidy, while the costs of additional displacement are a maximum of 2.1 billion 
Euro. Under the various assumptions about additional displacement, our proposal would still save the public budget between 3.6 and 5.6 billion Euro per year.

With an elasticity of 0.7 , labor demand increases by 133.5 percent. Referring back to Figure 6, in this situation firms would hit the corner solution where employment has doubled. Since the reduction of marginal wages drops from 70 percent to 35 percent when the number of new employees reaches the number already employed, this creates a barrier to further employment. Nevertheless, the employment effect in the low-wage sector is immense: employment doubles, creating 2.1 million new jobs! The cost savings for public budgets are even larger than in the medium scenario: public expenditures fall by almost 6.8 billion Euro p.a.

Table 3: Aggregate cost and benefits at the different levels of government

\begin{tabular}{l|c|c|c|c|c}
\hline \hline $\begin{array}{l}\text { Savings (+)/ } \\
\text { Costs (-) }\end{array}$ & $\begin{array}{c}\text { Federal } \\
\text { Level }\end{array}$ & States & $\begin{array}{c}\text { Munici- } \\
\text { palities }\end{array}$ & $\begin{array}{c}\text { Social } \\
\text { Insurances }\end{array}$ & Total \\
\hline \hline Savings (according to Table 2) & $+11,573.42$ & +277.83 & $+2,854.75$ & $+1,168.26$ & +15.874 .27 \\
Costs of stock subsidy & $-10,242.86$ & --- & --- & --- & $-10,242.86$ \\
Costs of additional & $-1,028.87$ & --- & --- & --- & $-1,028.87$ \\
displacement & & & & & \\
Fiscal effect (in mill. Euro p.a.) & +301.70 & +277.83 & $+2,854.75$ & $+1,168,26$ & $+4,602.54$ \\
\hline \hline
\end{tabular}

Source: own calculations.

Note: The results refer to the scenario with a labor demand elasticity of 0.5 and 50 percent additional displacement.

Even under pessimistic assumptions, the expected employment effects of the Magdeburg Alternative would be substantial. In most cases, the public budget would also be relieved. Table 3 shows how the different levels of government participate fiscally. For the medium scenario (elasticity of 0.5 and 50 percent additional displacement), all levels of government, i.e. the federal level, the states, municipalities, and social insurances, would gain. Municipalities, in particular, would gain substantially because they would have to spend 2.8 billion Euro per year less on housing. In 2004, the federal employment agency spent, on average, 4,455 Euro on active labor market policy per unemployed person (Federal 
Employment Agency 2005). Our proposal would make many of these programs redundant, so that we could expect additional savings not yet considered in Table 2.

\section{Conclusion}

The main reasons for low-skilled workers being at a particularly high risk of becoming unemployed apply to each and every industrial nation, and the resulting high levels of unemployment among low-skilled individuals are a problem for all developed countries. Technical progress and the high competitiveness of low-wage countries come at the cost of the job prospects of low-skilled workers everywhere. International comparisons show, however, that OECD countries have experienced greatly varying degrees of success in the struggle against low-skilled unemployment. There are two reasons for this. First, institutional settings vary considerably from one OECD country to another. Thus Anglo-Saxon countries are characterized by a significantly higher level of labor market flexibility than Continental European and Scandinavian countries are. A considerable variation in tax burdens and social security contributions also exist among the different countries. However, these differences alone do not provide an adequate explanation for the varying unemployment rates of lowskilled workers. And so, second, the different labor market policies must also be included in any explanation.

The flexible labor markets in the USA and the UK enable workfare instruments to be used to solve the dilemma of too low a labor productivity, as measured by some minimum level of existence, by shoring up the market wage with a subsidy of net wages. This approach is problematic in the regulated labor markets of Continental Europe because rigid wages prevent subsidies from leading to a stimulation of demand for low-skilled jobs. The interaction between low productivity and high social security contributions can then also lead to high levels of low-skilled unemployment in these regulated labor markets, but not necessarily so. Scandinavian countries have solved this problem by creating a high level of public sector employment. However, this approach can only be recommended if public sector employment emulates the jobs that would otherwise be created in the private sector under flexible labor 
market conditions as closely as possible. This goal can be best achieved by the government providing incentives to create jobs directly in the private sector.

All the attempts to reduce low-skilled unemployment have one thing in common. It is wage subsidies provided by the state, in whatever form, that are supposed to close the gap between the low productivity of the low-skilled and the minimum existence level. This does not mean, however, that it does not matter how this medicine is administered. At first glance, it would seem that a satisfactory level of success could only be achieved if the labor market were to be deregulated to a great extent. In this article, we have attempted to show that this is not necessarily the conclusion that needs to be drawn. On the contrary, the Magdeburg Alternative shows that a marginal employment subsidy that lowers gross wages can also be applied in the presence of collective wage bargaining and the achievement of the unions' goal of rigid wages.

The decisive point for a gross wage subsidy is the elimination of "revolving-door" effects and displacement effects. If it does not succeed in preventing firms from exploiting it to replace incumbent workers with subsidized workers, any reform linked to the demand side of the labor market is doomed to failure. This direct exchange of incumbent workers with subsidized workers can easily be prevented by linking the subsidy to a requirement that the number of employees in a firm should increase. By using double subsidization, i.e. the payment of a subsidy not only for the new employee but also for the incumbent employee, the outsourcing of employment is also made unattractive by the Magdeburg Alternative. And this is the decisive trick of the Magdeburg Alternative, because by doing so not only is outsourcing prevented. Massive incentives for the generation of further jobs are also created and the funding of the reform is secured.

In principle, this reform harnesses windfall gains, which one would generally attempt to avoid: firms are also able to have their incumbent employees subsidized, but only if the firms do what is desired, and that is create new jobs. The creation of these additional jobs means that the reform can be funded since a debit is always accompanied by a credit. For this reason, the Magdeburg Alternative not only creates 1.7 million new jobs, but also helps to consolidate the budget. 


\section{References}

Acemoglu, D. (2002): “Technical Change, Inequality, and the Labor Market”, Journal of Economic Literature 40, 7-72.

Addison, J., L. Bellmann, T. Schank and P. Teixeira (2005): The Demand for Labor: An Analysis Using Matched Employer-Employee Data from the German LIAB. Will the High Unskilled Worker Own-Wage Elasticity Please Stand Up?, IZA Discussion Paper No. 1780, Bonn.

Besley, T. and S. Coate (1992): "Workfare versus Welfare: Incentive Arguments for Work Requirements in Poverty-Alleviation Programs”, American Economic Review 82, 249-261.

Bishop, J. und R. Haveman (1979): „Selective Employment Subsidies: Can Okun’s Law Be Repealed?“, American Economic Review 69, 124-130.

Borjas, G. (2000): Labor Economics, $2^{\text {nd }}$ ed., Boston: McGraw-Hill.

Boss, A. and T. Elender (2005): Incentives to Work: The Case of Germany, Kiel Working Paper No. 1237, Kiel Institute of World Economics.

Cahuc, P. and A. Zylberberg (2004): Labor Economics, Cambridge: MIT Press.

Chiarella, C. und A. Steinherr (1982): Marginal Employment Subsidies: An Effective Policy to Generate Employment, European Commission Economic Papers No. 9, Brussels.

Corsetti, G. et al. (2002): EEAG European Economic Advisory Group at CESifo: Report on the European Economy 2002, CESifo Forum, Munich.

Daveri, F. and G. Tabellini (2000): “Unemployment, Growth, and Taxation in Industrial Countries”, Economic Policy 30, 49-104.

Falk, M. and B. Koebel (2002): “Outsourcing, Imports, and Labour Demand", Scandinavian Journal of Economics 104, 567-586.

Federal Employment Agency (2005): Arbeitsmarkt 2004, Amtliche Nachrichten der Bundesagentur für Arbeit 53, Nürnberg.

Feist, H. and R. Schöb (1998): "Workfare in Germany and the Problem of Vertical Fiscal Externalities", Finanzarchiv 55, 461-480.

German Bundestag (1998): “Antwort der Bundesregierung auf die Große Anfrage der Abgeordneten Ulf Fink, u.a.“, Bundestagsdrucksache 13/10759.

German Trade Union Federation (2003): Mut zum Umsteuern - Für Wachstum, Beschäftigung und soziale Gerechtigkeit, Hintergrundpapier für eine wirtschafts- und sozialpolitische Reformagenda des DGB

Hake, L. and P. Kaukewitsch (2001): "Ergebnisse der Lohnstatistik für 2000”, Wirtschaft und Statistik 5, 389401.

Hamermesh, D. (1993): Labor Demand, Princeton: Princeton University Press.

Hart, R. (1989): “The Employment and Hours Effect of a Marginal Employment Subsidy”, Scottish Journal of Political Economy 36, 385-395.

Hijzen, A., H. Görg, and R. Hine (2005): "International Outsourcing and the Skill Structure of Labour Demand in the United Kingdom”, Economic Journal 115, 860-878.

James, H. (1988): Deutschland in der Weltwirtschaftskrise 1924-1936, DVA: Stuttgart.

Johnson, G., and F. Stafford (1999): “The labor market implications of international trade”, in O. Ashenfelter and D. Card (eds): Handbook of Labor Economics, Vol. 3, Amsterdam: North-Holland.

Kaldor, N. (1936): “Wage subsidies as a remedy for unemployment”, Journal of Political Economy 44, 721-742.

Kopits, G. (1978): "Wage Subsidies and Employment: An Analysis of the French Experience”, IMF Staff Papers 25, 494-527. 
Layard, R. (1979): "The Cost and Benefits of Selective Employment Policies: The British Case”, British Journal of Industrial Relations 17, 187-204.

Layard, R. and S. Nickell (1980): “The Case for Subsidizing Extra Jobs”, Economic Journal 90, 51-73.

Lindbeck, A. and D. Snower (1988): The Insider-Outsider Theory of Employment and Unemployment, Cambridge: MIT Press.

Lindbeck, A. and D. Snower (2001): “Insiders versus Outsiders”, Journal of Economic Perspectives 15, 165188.

Marcon, H. (1974): Arbeitsbeschaffungspolitik der Regierungen Papen und Schleicher, Bern: Lang.

OECD (2003): Employment Outlook 2003. Towards More and Better Jobs, OECD:Paris.

OECD (2004): Taxing Wages 2003-2004, OECD: Paris.

OECD (2005): Employment Outlook 2005, OECD: Paris.

Orszag, J. M., and D. Snower (2000): "The Effectiveness of Employment Vouchers: A Simple Approach”, German Economic Review 1, 385-419.

Orszag, J. M., and D. Snower (2003): “Designing Employment Subsidies”, Labour Economics 10, 557-572.

Oswald, A. (1984): “Three Theorems on Inflation Taxes and Marginal Employment Subsidies”, Economic Journal 94, 599-611.

Perloff, J. und M. Wachter (1979): „The New Jobs Tax Credit: An Evaluation of the 1977-78 Wage Subsidy Program“, American Economic Review 69, 173-179.

Phelps, E. (1997): Rewarding Work. How to Restore Participation and Self-Support to Free Enterprise, Cambridge: Harvard University Press.

Rehn, G. (1982): Anti-Inflationary Expansion Policies (With Special Reference to Marginal Employment Premiums), Swedish Institute for Social Research Occasional Papers Nr. 4, Stockholm.

Scharpf, F. (2000): "Economic Changes, Vulnerabilities, and Institutional Capabilities", in F. Scharpf and V. Schmidt, Welfare and Work in the Open Economy, Vol. 1, Oxford, Oxford University Press, 21-124.

Schmidt, G. (1979): „The Impact of Selective Employment Policy: The Case of a Wage-Cost Subsidy Scheme in Germany 1974-75“, Journal of Industrial Economics 27(4), 339-358.

Schöb, R. (2002): “Public Profit Sharing”, Kyklos 55.2002, 523-542.

Schöb, R. and J. Weimann (2003): "Kombilohn: Die Magdeburger Alternative”, Perspektiven der Wirtschaftspolitik 4, 1-16.

Schöb, R. and J. Weimann (2005): Arbeit ist machbar. Die Magdeburger Alternative: Eine sanfte Therapie für Deutschland, $4^{\text {th }}$ ed., Dößel: Janos Stekovics Verlag.

Sinn, H.-W. et al. (2002): “Aktivierende Sozialhilfe: Ein Weg zu mehr Beschäftigung und Wachstum”, ifo Schnelldienst 55(9).

Sinn, H.-W. et al. (2006): “Aktivierende Sozialhilfe 2006: Das Kombilohn-Modell des ifo Instituts”, ifo Schnelldienst 59(2), 6-27.

Snower, D. (1994): “Converting Unemployment Benefits into Employment Subsidies”, American Economic Review 84, 65-70.

Whitley, J. D. and R. A. Wilson (1983): "The Macroeconomic Merits of a Marginal Employment Subsidy”, Economic Journal 93, 862-880.

WSI (2004): Tarifpolitischer Jahresbericht 2004, Düsseldorf: WSI. 


\section{CESifo Working Paper Series}

(for full list see www.cesifo-group.de)

1645 Burkhard Heer and Bernd Suessmuth, The Savings-Inflation Puzzle, January 2006

1646 J. Stephen Ferris, Soo-Bin Park and Stanley L. Winer, Political Competition and Convergence to Fundamentals: With Application to the Political Business Cycle and the Size of Government, January 2006

$1647 \mathrm{Yu}-\mathrm{Fu}$ Chen, Michael Funke and Kadri Männasoo, Extracting Leading Indicators of Bank Fragility from Market Prices - Estonia Focus, January 2006

1648 Panu Poutvaara, On Human Capital Formation with Exit Options: Comment and New Results, January 2006

1649 Anders Forslund, Nils Gottfries and Andreas Westermark, Real and Nominal Wage Adjustment in Open Economies, January 2006

1650 M. Hashem Pesaran, Davide Pettenuzzo and Allan G. Timmermann, Learning, Structural Instability and Present Value Calculations, January 2006

1651 Markku Lanne and Helmut Luetkepohl, Structural Vector Autoregressions with Nonnormal Residuals, January 2006

1652 Helge Berger, Jakob de Haan and Jan-Egbert Sturm, Does Money Matter in the ECB Strategy? New Evidence Based on ECB Communication, January 2006

1653 Axel Dreher and Friedrich Schneider, Corruption and the Shadow Economy: An Empirical Analysis, January 2006

1654 Stefan Brandauer and Florian Englmaier, A Model of Strategic Delegation in Contests between Groups, January 2006

1655 Jan Zápal and Ondřej Schneider, What are their Words Worth? Political Plans and Economic Pains of Fiscal Consolidations in New EU Member States, January 2006

1656 Thiess Buettner, Sebastian Hauptmeier and Robert Schwager, Efficient Revenue Sharing and Upper Level Governments: Theory and Application to Germany, January 2006

1657 Daniel Haile, Abdolkarim Sadrieh and Harrie A. A. Verbon, Cross-Racial Envy and Underinvestment in South Africa, February 2006

1658 Frode Meland and Odd Rune Straume, Outsourcing in Contests, February 2006

1659 M. Hashem Pesaran and Ron Smith, Macroeconometric Modelling with a Global Perspective, February 2006 
1660 Alexander F. Wagner and Friedrich Schneider, Satisfaction with Democracy and the Environment in Western Europe - a Panel Analysis, February 2006

1661 Ben J. Heijdra and Jenny E. Ligthart, Fiscal Policy, Monopolistic Competition, and Finite Lives, February 2006

1662 Ludger Woessmann, Public-Private Partnership and Schooling Outcomes across Countries, February 2006

1663 Topi Miettinen and Panu Poutvaara, Political Parties and Network Formation, February 2006

1664 Alessandro Cigno and Annalisa Luporini, Optimal Policy Towards Families with Different Amounts of Social Capital, in the Presence of Asymmetric Information and Stochastic Fertility, February 2006

1665 Samuel Muehlemann and Stefan C. Wolter, Regional Effects on Employer Provided Training: Evidence from Apprenticeship Training in Switzerland, February 2006

1666 Laszlo Goerke, Bureaucratic Corruption and Profit Tax Evasion, February 2006

1667 Ivo J. M. Arnold and Jan J. G. Lemmen, Inflation Expectations and Inflation Uncertainty in the Eurozone: Evidence from Survey Data, February 2006

1668 Hans Gersbach and Hans Haller, Voice and Bargaining Power, February 2006

1669 Françoise Forges and Frédéric Koessler, Long Persuasion Games, February 2006

1670 Florian Englmaier and Markus Reisinger, Information, Coordination, and the Industrialization of Countries, February 2006

1671 Hendrik Hakenes and Andreas Irmen, Something out of Nothing? Neoclassical Growth and the 'Trivial' Steady State, February 2006

1672 Torsten Persson and Guido Tabellini, Democracy and Development: The Devil in the Details, February 2006

1673 Michael Rauber and Heinrich W. Ursprung, Evaluation of Researchers: A Life Cycle Analysis of German Academic Economists, February 2006

1674 Ernesto Reuben and Frans van Winden, Reciprocity and Emotions when Reciprocators Know each other, February 2006

1675 Assar Lindbeck and Mats Persson, A Model of Income Insurance and Social Norms, February 2006

1676 Horst Raff, Michael Ryan and Frank Staehler, Asset Ownership and Foreign-Market Entry, February 2006 
1677 Miguel Portela, Rob Alessie and Coen Teulings, Measurement Error in Education and Growth Regressions, February 2006

1678 Andreas Haufler, Alexander Klemm and Guttorm Schjelderup, Globalisation and the Mix of Wage and Profit Taxes, February 2006

1679 Kurt R. Brekke and Lars Sørgard, Public versus Private Health Care in a National Health Service, March 2006

1680 Dominik Grafenhofer, Christian Jaag, Christian Keuschnigg and Mirela Keuschnigg, Probabilistic Aging, March 2006

1681 Wladimir Raymond, Pierre Mohnen, Franz Palm and Sybrand Schim van der Loeff, Persistence of Innovation in Dutch Manufacturing: Is it Spurious?, March 2006

1682 Andrea Colciago, V. Anton Muscatelli, Tiziano Ropele and Patrizio Tirelli, The Role of Fiscal Policy in a Monetary Union: Are National Automatic Stabilizers Effective?, March 2006

1683 Mario Jametti and Thomas von Ungern-Sternberg, Risk Selection in Natural Disaster Insurance - the Case of France, March 2006

1684 Ken Sennewald and Klaus Waelde, "Itô's Lemma" and the Bellman Equation for Poisson Processes: An Applied View, March 2006

1685 Ernesto Reuben and Frans van Winden, Negative Reciprocity and the Interaction of Emotions and Fairness Norms, March 2006

1686 Françoise Forges, The Ex Ante Incentive Compatible Core in Exchange Economies with and without Indivisibilities, March 2006

1687 Assar Lindbeck, Mårten Palme and Mats Persson, Job Security and Work Absence: Evidence from a Natural Experiment, March 2006

1688 Sebastian Buhai and Coen Teulings, Tenure Profiles and Efficient Separation in a Stochastic Productivity Model, March 2006

1689 Gebhard Kirchgaessner and Silika Prohl, Sustainability of Swiss Fiscal Policy, March 2006

1690 A. Lans Bovenberg and Peter Birch Sørensen, Optimal Taxation and Social Insurance in a Lifetime Perspective, March 2006

1691 Moritz Schularick and Thomas M. Steger, Does Financial Integration Spur Economic Growth? New Evidence from the First Era of Financial Globalization, March 2006

1692 Burkhard Heer and Alfred Maussner, Business Cycle Dynamics of a New Keynesian Overlapping Generations Model with Progressive Income Taxation, March 2006 
1693 Jarko Fidrmuc and Iikka Korhonen, Meta-Analysis of the Business Cycle Correlation between the Euro Area and the CEECs, March 2006

1694 Steffen Henzel and Timo Wollmershaeuser, The New Keynesian Phillips Curve and the Role of Expectations: Evidence from the Ifo World Economic Survey, March 2006

1695 Yin-Wong Cheung, An Empirical Model of Daily Highs and Lows, March 2006

1696 Scott Alan Carson, African-American and White Living Standards in the $19^{\text {th }}$ Century American South: A Biological Comparison, March 2006

1697 Helge Berger, Optimal Central Bank Design: Benchmarks for the ECB, March 2006

1698 Vjollca Sadiraj, Jan Tuinstra and Frans van Winden, On the Size of the Winning Set in the Presence of Interest Groups, April 2006

1699 Martin Gassebner, Michael Lamla and Jan-Egbert Sturm, Economic, Demographic and Political Determinants of Pollution Reassessed: A Sensitivity Analysis, April 2006

1700 Louis N. Christofides and Amy Chen Peng, Major Provisions of Labour Contracts and their Theoretical Coherence, April 2006

1701 Christian Groth, Karl-Josef Koch and Thomas M. Steger, Rethinking the Concept of Long-Run Economic Growth, April 2006

1702 Dirk Schindler and Guttorm Schjelderup, Company Tax Reform in Europe and its Effect on Collusive Behavior, April 2006

1703 Françoise Forges and Enrico Minelli, Afriat's Theorem for General Budget Sets, April 2006

1704 M. Hashem Pesaran, Ron P. Smith, Takashi Yamagata and Liudmyla Hvozdyk, Pairwise Tests of Purchasing Power Parity Using Aggregate and Disaggregate Price Measures, April 2006

1705 Piero Gottardi and Felix Kubler, Social Security and Risk Sharing, April 2006

1706 Giacomo Corneo and Christina M. Fong, What's the Monetary Value of Distributive Justice?, April 2006

1707 Andreas Knabe, Ronnie Schoeb and Joachim Weimann, Marginal Employment Subsidization: A New Concept and a Reappraisal, April 2006 